https://www.scilook.eu/index.php/slif/article/view/slif19-01-039 DOI: 10.30888/2415-7538.2020-19-01-039

\title{
УДК 656.
}

\section{THE NATURE OF PHYSICAL WEAR OF VEHICLE WAREHOUSE ПРИРОДА ФІЗИЧНОГО ЗНОСУ АВТОРУХОМОГО СКЛАДУ}

\author{
Василянська О. / Vasilyanska O \\ master/Mazicmp
}

Ковальчук К. / Kovalshuk K master/Mazicmp

Лямзин A. / Lyamzin A.

Candidate of Engineering Sciences, Docent/к.m.н.,доиент Pryazovskyi State Technical University (PSTU), Mariupol, 7, 87555 Приазовський державний технічний університет, Маріуполь, вул. Університетьска, 7, 87555

Анотація. У сучасних економічних умовах розвиток господарства у значній мірі залежить від рімень проблеми стабільного функціонування та розвитку залізничного транспорту. На поточному етапі реорганізачії залізничної відбиття ідеальний прочес становлення активів, зміна власників, формування центрів отримання прибутку. У даних умовах одного з важливих питань питання встає питання оновлення підвісного складу залізничного транспорту та транспортної інфраструктури.

Знос рухомого складу - одна з самих серйозних проблем для відображення. Ситуація щзодо благополучної з оновленням парку рухомого складу, як найбільший попит та дохідного сегмента ринку транспортних послуг - вантажоперевезення.

Розвиток економіки напряму пов'язано з прочесом модернізації засобів виробництва реального сектора. У сучасній Украӥни основним утворенням розвитку та індексом якісного перетворення економічної структури є процес імпортозамещення продукції та послуг зарубіжних країн-партнерів отечественними аналогами. Зниження рівня спроми на виробництво імпортних компаній з одночасним розвитком власного виробництва може забезпечуватися виключно в прочесі взаємодії суб'єктів ринкових відносин на основі понятних та об'єктивних критеріїв.

Ключевые слова: експортні автомобільні перевезення, фізичний знос рухомого складу, контролінг здійснення послуги вантажоперевезення.

\section{Ветуп.}

Сьогодні вантажоперевезення одна 3 найбільш затребуваних послуг. Стосується це і дрібних приватних підприємств, і великих компаній, i фізичних осіб. Перевезення вантажів необхідне абсолютно всім. Велика популярність на послугу привела до виникнення великої кількості фірм, що пропонують виконати доставку швидко i якісно. Для вибору надійної транспортної компанії i рухомого складу, який відповідає Свропейським стандартам технічної надійності, спроможної виконати перевезення на найвищому рівні, необхідно:

- Знайти перевізника, що відповідає всім вашим вимогам. Важливим аспектом $\epsilon$ грамотна постановка завдань, які повинна буде виконати транспортна компанія. Так, міжнародні вантажні перевезення дуже сильно відрізняються від вантажоперевезень між регіонами. В першому випадку довірити роботу можна тільки великій компанії, що має і великий досвід у даній області, і штат кваліфікованих фахівців, і відповідний автопарк, в другому - настільки серйозні критерії не принципові. 
- Рішення завдання доставки будь-якого вантажу повинне виконуватися якісно і оперативно. Перевірити даний фактор не складно: достатньо почитати відгуки про компанії, дізнатися як відбувається контроль і надання інформації про хід виконання вантажоперевезення. У разі відсутності коментарів про діяльність фірми, варто задуматися про професіоналізм перевізника.

- Необхідність наявності технічно надійного автопарку, обладнаного різними видами техніки. Слід враховувати, що чим більше посередників бере участь в вантажоперевезенні, тим складніше і довше відбувається виконання робіт. Оптимальним варіантом є транспортна компанія вантажоперевезень, здатна самостійно виконати розбирання і упаковку вантажу, завантаження i вивантаження з використанням спеціальної такелажної техніки, що має великий автопарк, в якому знайдеться оптимальний транспорт для різних категорій вантажів.

- Контролінг здійснення послуги вантажоперевезення - це один з основних критеріїв вибору перевізника. Не варто довіряти компаніям, які пропонують дуже низьку вартість за послуги. Як правило, це стосується нових фірм, які не мають свого автопарку, а також «сірих перевізників», які працюють нелегально. Звичайно, низька ціна виглядає дуже заманливо. Однак, слід враховувати, що в цьому випадку ви бачите вартість за годину роботи, а не кінцеву ціну за перевезення. У такому випадку ви сплачуваєте і за простої в заторах, i за час, необхідний для завантаження і вивантаження вантажу. В результаті кінцева вартість виходить значно вище. Джерело: [1]

\section{Загальний текст}

Фізичний знос являє собою природний процес погіршення характеристик обладнання у час його експлуатації під впливом багатьох чинників: тертя, корозія, старіння матеріалів, вібрація, якість обслуговування і інші. Зростання фізичного зносу призводить до збільшення ймовірності аварійних відмов обладнання, веде до зменшення залишкового терміну служби всього комплекту обладнання або деяких його вузлів і деталей.

Існують п'ять методів оцінки фізичного зносу обладнання і транспортних засобів (рис.1):

1. метод экспертизы физического состояния объекта;

2. экспертно-аналитический метод;

3. метод эффективного возраста;

4. метод средневзвешенного хронологического возраста;

5. метод ухудшения главного параметра.

У багатьох виданнях на тему оцінки рівня зносу машин запропоновано багато методик по визначенню величини накопиченого зносу, проте зупинимося на методиці аналізу ринку.

Існує багато суперечок про переваги i недоліки, однак корисність їх визначається отриманням більш точних i достовірних результатів. До основних недоліків можна віднести - вузьке застосування, а саме для одиниць, масово представлених для реалізації на вторинному ринку.

Проведемо дослідження моделі на прикладі розрахунку величини накопиченого зносу для автотподвіжного складу, а саме спеціалізованих 
транспортних одиниць.

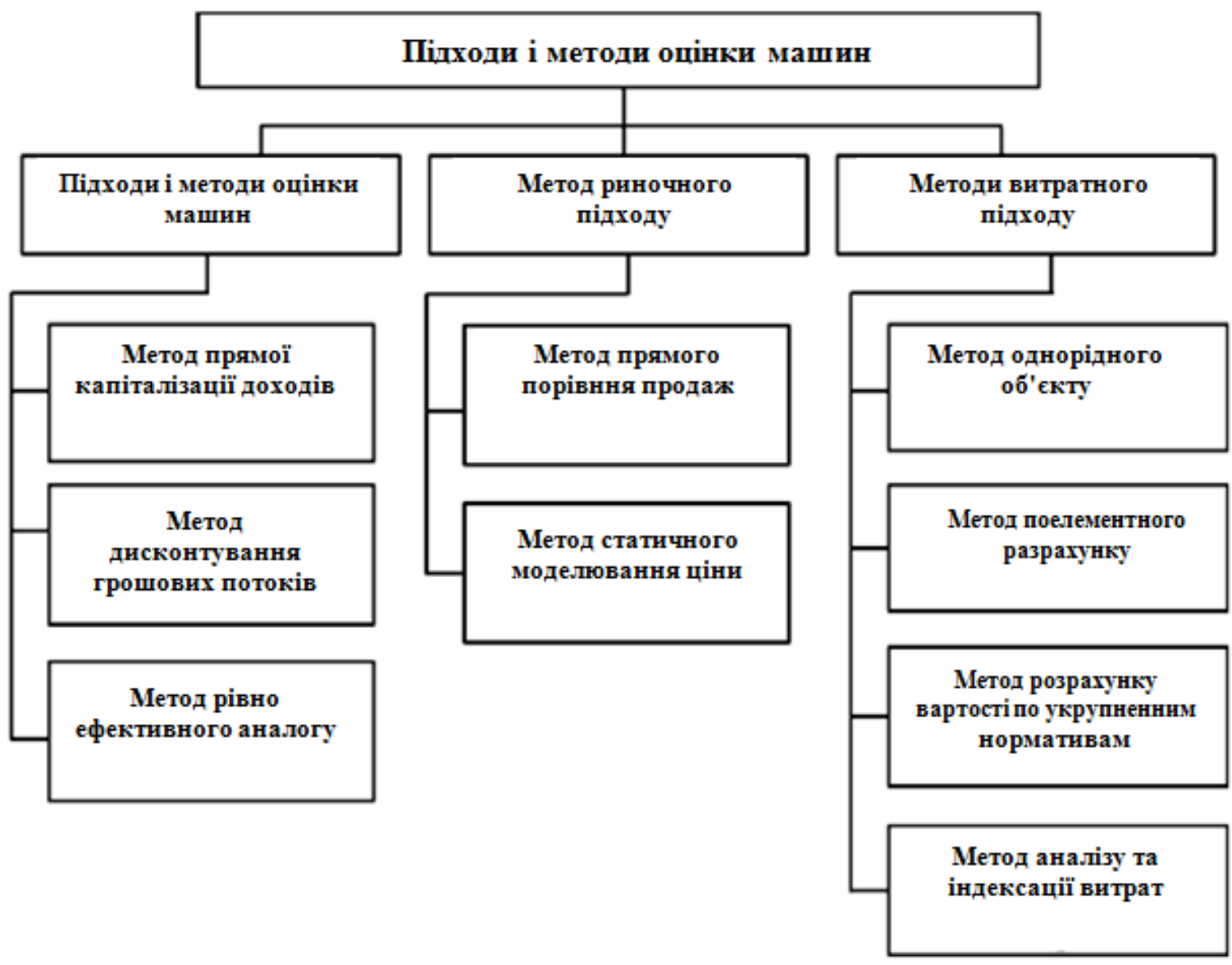

Рисунок 1 - Зміст підходів до оцінки зношеності машин

В цілому, було оброблено 100 записів про терміни експлуатації рухомого складу. Крім того, необхідно відзначити ряд особливостей представленої інформації (рис.2):

1) у складі ряду об'єктів, позиціонуються в зібраної бази даних як спецрухомий склад, мають знос не відповідає експлуатаційним характеристикам, це об'єкти, що мають «екстремально» мінімальні або максимальні;

2) у зв'язку з тривалим терміном експозиції має місце повторення ряду об'єктів в інформаційній базі, що містять дані про знос (різні дати публікацій зносу одного і того ж об'єкта). Аналіз баз даних показав, що число таких повторень (з однаковою моделлю, однаковою адресою та однаковою мірою зношеності) досягає 2 і більше разів;

3) відносно більшості спецрухомого складу в базах даних відсутня інформація про технічні характеристики.

Таким чином, аналізуючи різницю в зносі потенційно нових i експлуатованих транспортних одиниць, ми отримуємо дані по впливу сукупного зносу (у випадку з спецскладом нами отримано загальний знос, що включає фізичний знос і зовнішній знос при переході на вторинний ринок де працюють «сірі перевізники»). 


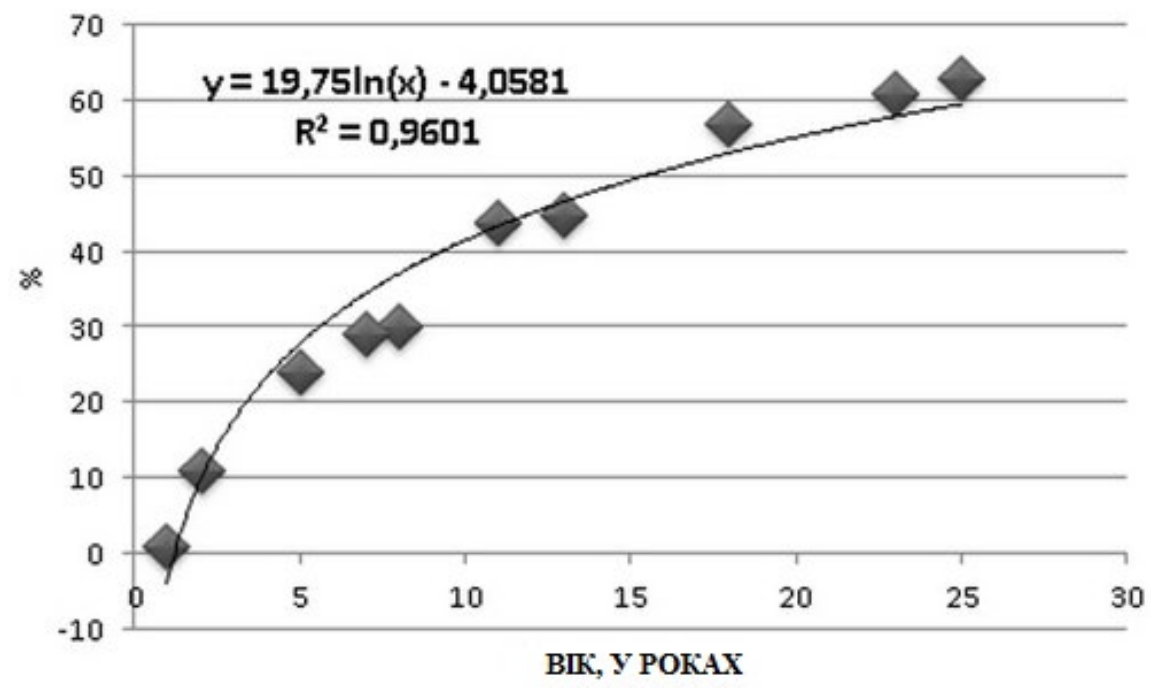

\section{Рисунок 2 - Величина накопиченого зносу спецрухомого складу на підставі інформації, що публікусться}

\section{Висновки.}

У розрізі проведно дослідження динаміки вантажопотоків в міжрегіональному i міжнародному сполученнях були отримані наступні результати: в розрізі вантажів у фізичному вираженні (тоннах) значно додали поставки з СС в Україну автотранспорту і запчастин, фруктів, напоїв i спиртів. Знизилися постачання м'яса i харчових субпродуктів, регенерованої паперу i картону, будматеріалів; в розрізі вантажів 3 України в СС на автотранспорті в експортному грузопотоке найбільше збільшилися обсяги тварин і рослинних жирів, товарів для будинку, скла і скляних виробів, відходів харчової промисловості і кормів для тварин. Знизилися експортні автомобільні перевезення дерева і дерев'яних виробів, виробів із заліза та сталі, алюмінію і виробів 3 нього, цукру; статистичні показники автотранспортних вантажоперевезень підраховуються в Україні не цілком коректно. Реальна кількість автоперевезень i автоперевізників в кілька разів вище цифр статистики. Звідси виникає істотна розбіжність між реальною кількістю автоперевізників і обсягом наданих ними послуг і даними офіційної статистики.

\section{Литература:}

1. Бауерсокс Д. Логістика експлуатації рухомого складу. 2-ге вид. Пер. с англ. / Д. Бауерсокс, Д. Клосс. - М.: ЗАО «Олімп-Бізнес», 2006. 640 с.

Abstract. In modern economic conditions, economic development largely depends on solutions to the problem of stable operation and development of railway transport. At the current stage of reorganization of the railway reflection is an ideal process of formation of assets, change of owners, the formation of profit centers. In these circumstances, one of the important issues is the question of updating the suspension of railway transport and transport infrastructure.

Rolling stock wear is one of the most serious problems for display. The situation is relatively prosperous with the renewal of the rolling stock, as the greatest demand and profitable segment of the market of transport services - freight. 
The development of the economy is directly related to the process of modernization of the means of production of the real sector. In modern Ukraine, the main formation of development and the index of qualitative transformation of the economic structure is the process of import substitution of products and services of foreign partner countries by domestic counterparts. Reducing the level of demand for production of imported companies with the simultaneous development of their own production can be provided only in the process of interaction of market participants on the basis of clear and objective criteria..

Key words: export road transport, physical wear of rolling stock, controlling the implementation of freight services.

Статья отправлена: 18.11.2020 г.

(C) Василянська О.

(C) Ковальчук К.

(c) Лямзин А. 